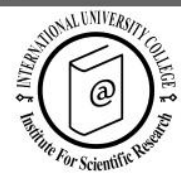

\title{
European tourist destinations on the internet search engines
}

\author{
Estrella Díaz ${ }^{1 *}$, Juan José Blázquez ${ }^{2}$ and David Martín-Consuegra ${ }^{3}$
}

Received: 28/10/2011 Accepted: 15/02/2012

\begin{abstract}
${ }^{1}$ Department of Marketing, University of Castilla-La Mancha, Ronda de Toledo, s/n. 13071-Ciudad Real, Spain; tel. +34 902204100 - Ext. 6439; fax.+34 902204 130; e-mail: estrella.diaz@uclm.es

${ }^{2}$ Department of Marketing, University of Castilla-La Mancha, Avenida Real Fábrica de la Seda, s/n. 45600Talavera de la Reina (Toledo), Spain; tel. +34 925721010 - Ext. 5652; fax. +34 902204 130; e-mail: juan.blazquez@uclm.es

3 Department of Marketing, University of Castilla-La Mancha, Ronda de Toledo, s/n. 13071-Ciudad Real, Spain; tel. +34 902204100 - Ext. 3545; fax. +34 902204 130; e-mail: david.martin@uclm.es

* Corresponding author
\end{abstract}

\section{Abstract}

This paper examines the accessibility and visibility of tourist destinations in a search engine as an opportunity to influence destination competitiveness. The study employed a research design that simulates a traveller's use of four search engines for travel planning by using the concept "tourism" and a set of pre-defined keywords in combination with European tourist destination names. The results of this research reveal that search engines index a great number of websites related to tourism, although the visibility of tourist destinations is extremely low.

(C) 2012 International University College. All rights reserved

Keywords: destination competitiveness, online tourism domain, search engine, visibility

Citation: Díaz, E., J. J. Blázquez, D. Martin-Consuegra (2012) European tourist destinations on the internet search engines. European Journal of Tourism Research 5(2), pp. 171-175

\section{Introduction}

Competitiveness has become a central point of tourism policy, especially on tourism destination (Buhalis, 2000; Dwyer and Kim, 2003). In this sense, maintaining competitiveness in the long-term and satisfying tourist demand may require the use of new technologies and integrated online marketing communication strategies, such as websites and search engines by the tourist sector (So and Morrison, 2003). In the field of tourism, the recent evolution of Internet technology has shown that search engines are indeed one of the most persuasive media for destinations to influence tourists' travel planning process (Hwang et al., 2006). Furthermore, from the point of view of tourist enterprises, being indexed in a search engine and visible as a search result provides an advantage to increase destination competitiveness (Xiang and Fesenmaier, 2006).

However, due to the size of the Internet and the different quality of websites, many issues have emerged with respect to the way search engines index and represent the online world. Consequently, although search engines can potentially retrieve millions of search results 
based on a specific query, only a relatively small number of them are presented to the user. The visibility of tourism therefore depends mainly on the classification and position of results (Xiang and Fesenmaier, 2005; Xiang, Wöber and Fesenmaier, 2008). In fact, most of the users of search engines rarely go beyond the first three result pages (30 results) and the majority never look beyond the top 2 results.

Built upon a number of recent studies on search engines and the online tourism domain (Wöber, 2006; Xiang et al., 2008; Wöber and Fesenmaier, 2009; Pan et al., 2011), the objective of this research is to provide an understanding of the representation of fifty European tourist destinations in four search engines, with the main aim of testing tourist destination visibility. This analysis will therefore try to answer the following questions:

1) Which is the general visibility ratio of the destinations (capital and non-capital cities) in each of the search engines analyzed in this study? and,

2) Which is the presence of specific tourist information available in each search engine and for each of the destinations (capital and non-capital cities) analyzed here?

\section{Methodology}

The sample of tourist destinations used consisted of 50 European cities, according to the number of visitors each destination received (Bremner, 2008). Furthermore, the fifty European destinations were divided into two groups depending on whether these cities were the capital of the country (21 cities) or not country capitals (29 cities). In order to assess the presence of each of the tourist destinations by the search engines, ten keywords related to tourist destinations were selected: "tourism", "accommodation", "activities", "areas", "attractions", "events", "information", "restaurants", "shopping" and "places" (i.e. Xiang and Fesenmaier, 2006; Xiang et al., 2008). Finally, four search engines used in this study to determine the representation of tourism in each destination were Google, Yahoo, Microsoft and Ask, as they are the most widely used (Lewandowski, 2008).

The presence of tourism in each destination as provided by each of the four search engines 172 was measured in two steps. Firstly, the presence of tourism in general was measured for each group (capital and non-capital cities). Secondly, the procedure continued with an analysis of the presence of tourism in terms of tourist categories for each city group. In order to do that, the name of the city and the term "tourism" or the name of each of the nine tourist categories were entered together as search keywords in the four search engines used here. Search results were noted as follows: the total number of indexed websites and the number of results found by the engine. These measures were then used to calculate the visibility ratio for each question, dividing the number of results found by the total number of websites indexed in the search engine (Xiang et al., 2008). The data for this study were collected during the third quarter of 2010.

\section{Results}

Table 1 shows the results of the European tourist destinations that are the country's capital city and not capitals. Tourist destinations in grey shade are those with highest visibility ratios, while those with the lowest ratios are not shaded. The results of this analysis indicate that London, Paris and Berlin were the capitals destinations which provide lower visibility ratio. In contrast, Tallinn, Reykjavik and Bratislava obtain the highest. Similarly, Nice, Hamburg and Barcelona were the non-capital tourist destinations which presented lower visibility ratio, while Gothenburg, Benidorm and Bruges offer the highest visibility ratio. Furthermore, regarding to visibility ratio, there are no significant differences between destinations that are country capitals and those that are not.

Analyses were also conducted to assess the presence of the tourist destinations in the search engines selected according to the tourist categories and are presented in Table 2; as can be seen, it focuses on highest and lowest presence of tourist categories in the four search engines where tourist destinations in grey shade are those with highest visibility rations, while those with the lowest ratios are not shaded. The results of this effort show that "information," "events" and "shopping" yield the lower visibility ratio mainly in capital destinations, although there are relevant varia- 
Díaz, E., J. Blázquez, D. Consuegra (2012) / European Journal of Tourism Research 5(2), pp. 171-175

Table 1. Representation of tourism in European destinations in search engines

\begin{tabular}{cccccccc}
\hline \multicolumn{2}{c}{ GOOGLE } & \multicolumn{2}{c}{ YAHOO } & \multicolumn{2}{c}{ MICROSOFT } & \multicolumn{2}{c}{ ASK } \\
\hline Capitals & $\begin{array}{c}\text { Visibility } \\
\text { ratio } \\
(\%)\end{array}$ & Capitals & $\begin{array}{c}\text { Visibility } \\
\text { ratio } \\
(\%)\end{array}$ & Capitals & $\begin{array}{c}\text { Visibility } \\
\text { ratio } \\
(\%)\end{array}$ & Capitals & $\begin{array}{c}\text { Visibility } \\
\text { ratio } \\
(\%)\end{array}$ \\
\hline London & 0.0001 & London & 0.0003 & London & 0.0003 & London & 0.0003 \\
\hline Paris & 0.0002 & Berlin & 0.0004 & Paris & 0.0004 & Berlin & 0.0006 \\
\hline Madrid & 0.0004 & Paris & 0.0004 & Berlin & 0.0004 & Paris & 0.0006 \\
\hline Lisbon & 0.0053 & Tallinn & 0.0080 & Tallinn & 0.0081 & Bratislava & 0.0391 \\
\hline Warsaw & 0.0042 & Bratislava & 0.0102 & Bratislava & 0.0101 & Reykjavik & 0.0514 \\
\hline Reykjavik & 0.0065 & Reykjavik & 0.0215 & Reykjavik & 0.0223 & Tallinn & 0.0538 \\
\hline Non-Capitals & $\begin{array}{c}\text { Visibility } \\
\text { ratio }\end{array}$ & Non-Capitals & $\begin{array}{c}\text { Visibility } \\
\text { ratio } \\
(\%)\end{array}$ & Non-Capitals & $\begin{array}{c}\text { Visibility } \\
\text { ratio } \\
(\%)\end{array}$ & Non-Capitals & $\begin{array}{c}\text { Visibility } \\
\text { ratio } \\
(\%)\end{array}$ \\
\hline Nice & 0.0002 & Nice & 0.0002 & Nice & 0.0002 & Nice & 0.0003 \\
\hline Barcelona & 0.0006 & Hamburg & 0.0007 & Hamburg & 0.0006 & Manchester & 0.0013 \\
\hline Manchester & 0.0006 & Barcelona & 0.0011 & Barcelona & 0.0011 & Hamburg & 0.0013 \\
\hline Krakov & 0.0078 & Bruges & 0.0183 & Bruges & 0.0176 & Bruges & 0.0502 \\
\hline Gothenburg & 0.0085 & Gothenburg & 0.0267 & Gothenburg & 0.0242 & Gothenburg & 0.0506 \\
\hline Benidorm & 0.0130 & Benidorm & 0.0284 & Benidorm & 0.0281 & Benidorm & 0.0726 \\
\hline
\end{tabular}

Table 2. Highest and lowest presence of tourist categories in search engines

\begin{tabular}{|c|c|c|c|c|c|c|c|c|}
\hline & \multicolumn{2}{|c|}{ GOOGLE } & \multicolumn{2}{|c|}{ YAHOO } & \multicolumn{2}{|c|}{ MICROSOFT } & \multicolumn{2}{|c|}{ ASK } \\
\hline & Destination & $\begin{array}{c}\text { Visibility } \\
\text { ratio } \\
(\%)\end{array}$ & Destination & $\begin{array}{c}\text { Visibility } \\
\text { ratio } \\
(\%)\end{array}$ & Destination & $\begin{array}{c}\text { Visibility } \\
\text { Ratio } \\
(\%)\end{array}$ & Destination & $\begin{array}{c}\text { Visibility } \\
\text { Ratio } \\
(\%)\end{array}$ \\
\hline \multirow{2}{*}{$\begin{array}{c}\text { Accommo- } \\
\text { dation }\end{array}$} & Gothenburg & 0.2859 & Bruges & 0.2519 & Gothenburg & 0.3448 & Gothenburg & 0.9950 \\
\hline & London & 0.0020 & London & 0.0023 & London & 0.0021 & London & 0.0057 \\
\hline \multirow{2}{*}{ Activities } & Benidorm & 0.2224 & Benidorm & 0.2410 & Benidorm & 0.2915 & Benidorm & 0.7752 \\
\hline & London & 0.0007 & Nice & 0.0007 & London & 0.0013 & London & 0.0033 \\
\hline \multirow{2}{*}{ Areas } & Benidorm & 0.2508 & Benidorm & 0.2950 & Benidorm & 0.2985 & Benidorm & 0.8403 \\
\hline & Paris & 0.0006 & London & 0.0007 & London & 0.0010 & London & 0.0025 \\
\hline \multirow{2}{*}{ Attractions } & Helsinki & 0.3447 & Benidorm & 0.3247 & Bratislava & 0.3690 & Bratislava & 1.4925 \\
\hline & London & 0.0027 & Nice & 0.0042 & London & 0.0045 & London & 0.0074 \\
\hline \multirow{2}{*}{ Events } & Benidorm & 0.2463 & Benidorm & 0.2370 & Benidorm & 0.3257 & Benidorm & 0.8130 \\
\hline & London & 0.0003 & Nice & 0.0005 & Nice & 0.0008 & London & 0.0011 \\
\hline \multirow{2}{*}{ Information } & Benidorm & 0.0892 & Benidorm & 0.0962 & Benidorm & 0.1065 & Benidorm & 0.2139 \\
\hline & London & 0.0001 & Nice & 0.0004 & London & 0.0005 & London & 0.0007 \\
\hline \multirow{2}{*}{ Restaurants } & Krakow & 0.1769 & Krakow & 0.1550 & Reykjavik & 0.2037 & Bratislava & 0.6116 \\
\hline & Nice & 0.0011 & Nice & 0.0011 & Nice & 0.0015 & Nice & 0.0037 \\
\hline \multirow{2}{*}{ Shopping } & Stockholm & 0.1991 & Gothenburg & 0.1603 & Benidorm & 0.2381 & Gothenburg & 0.6920 \\
\hline & Luxembourg & 0.0005 & Nice & 0.0005 & Nice & 0.0008 & London & 0.0024 \\
\hline \multirow{2}{*}{ Places } & Benidorm & 0.2172 & Benidorm & 0.0862 & Benidorm & 0.2632 & Innsbruck & 0.4902 \\
\hline & Nice & 0.0005 & Nice & 0.0003 & Nice & 0.0011 & Nice & 0.0022 \\
\hline
\end{tabular}


tions for each destination and search engine. Important, the results indicate that destinations with the biggest number of indexed websites correspond to the lowest visibility ratio. It is also relevant that the capitals with lowest visibility in search engines are exactly those that receive the greatest number of visitors.

\section{Conclusion}

The findings of the research revealed interesting dynamics in some of the key areas in online tourism. Firstly, the results obtained in this study indicate that although search engines index a huge number of websites with tourist content, the actual visibility and accessibility of websites created by tourist organizations related to the different destinations is quite low (Xiang et al., 2008). The low visibility of tourist websites in search engines reveals that there are few opportunities for actual interaction between online tourists and tourist businesses. It is, therefore, necessary to design tools for quicker and more effective information search, as well as strategies for better indexing capacity, improved information organization and useful (relevant and updated) information discrimination in all search fields, including tourism. Secondly, this study provides an understanding of the search queries employed. When specific keywords are used for online search, the search engines retrieve hundreds of websites containing them; however, only the most relevant and better designed websites, according to the search engine criteria, will be visible in the engine. It is therefore logical to assume that good-quality website design improves visibility. Finally, the research analyses the possible differences between search engines. From the results obtained here, we can conclude that there are no important differences between Google, Microsoft and Ask. However, Yahoo retrieved a significantly higher number of indexed websites, as a consequence of which it provides lower visibility ratios.

The results of the study offer some important managerial implications as tourism marketers are facing challenges resulting from the shift in distribution channels and the emergence of new media (Fesenmaier, 2007; Fesenmaier et al., 2011). In response to these changes, tourist organizations should make sure they are present in a significant number of search engines, because a high percentage of tourists use search engines and websites to make their buying decision. It would then be interesting for a tourist business that designs strategies to make sure that users will visualize their services in the search engine (Gretzel and Wöber, 2004; Ricci et al., 2005; Wöber, 2007; Wolk and Wöber, 2008). In this sense, Search Engine Marketing (SEM) is important in that it increases website visibility in online search engines (Xiang et al., 2009; Pan et al., 2011).

\section{References}

Bremner, C. (2008). Top 150 city destinations: London leads the way. Euromonitor International, URL: http://www. euromonitor.com/Top_150_City_Destin ations_London_Leads_the_Way (accessed on 30.01.2009).

Buhalis, D. (2000). Marketing the competitive destination of the future. Tourism Management, 21(1), 97-116.

Dwyer, L. \& C. Kim (2003). Destination competitiveness: determinants and indicators. Current Issues in Tourism, 6(5), 369-414.

Fesenmaier, D. (2007). Introduction: challenging destination promotion. Journal of Travel Research, 46(1), 3-4.

Fesenmaier, D., Xiang, Z., Pan, B. \& Law, R. (2011). A framework for search engine use for travel planning. Journal of Travel Research, 50(6), 587-601.

Gretzel, U. \& K. Wöber (2004). Intelligent search support: Building search term associations for tourism-specific search engines. Paper presented at the $\mathrm{XI}^{\text {th }}$ International Conference on Information Technology and Travel \& Tourism, ENTER, $26^{\text {th }}-28^{\text {th }}$ January 2004, Cairo, Egypt.

Hwang, Y., Gretzel, U., Xiang Z. \& Fesenmaier, D. (2006). Information search of travel decisions. In Fesenmaier, D., Werthner, H. \& Wöber, K. (eds) (2006). Destination recommendation systems: behavioral foundations and applications. Cambridge, MA: CAB international, 3-16.

Lewandowski, D. (2008). The retrieval effectiveness of web search engines: considering results descriptions. 
Journal of Documentation, 64(6), 915937.

Pan, B., Xiang, Z., Law, R. \& Fesenmaier, D. (2011). The dynamics of search engine marketing for tourist destinations. Journal of Travel Research, 50(4), 113.

Ricci, F., Wöber K., \& Zins, A. (2005). Recommendations by collaborative browsing. Paper presented at the $\mathrm{XII}^{\text {th }}$ International Conference on Information Technology and Travel \& Tourism, ENTER, $26^{\text {th }}-28^{\text {th }}$ January 2005, Innsbruck, Austria.

So, S. \& Morrison, A. (2003). Destination marketing organizations' web site users and nonusers: A comparison of actual visits and revisit intentions. Information Technology and Tourism, 6(2), 129139.

Wöber, K. (2006). Domain-specific search engines. In Fesenmaier, D., Werthner, H. \& Wöber, K. (eds) (2006). Destination recommendation systems: behavioral foundations and applications. Cambridge, MA: CAB international, 205-226.

Wöber, K. (2007). Similarities in information search of city break travellers - a web usage mining exercise. Paper presented at the $\mathrm{XIV}^{\text {th }}$ International Conference on Information Technology and Travel \& Tourism, ENTER, $24^{\text {th }}$. $26^{\text {th }}$ January 2007 , Liubliana, Slovenia.

Wöber, K. \& Fesenmaier, D. (2009). The management of city tourism in Europe. In Mazanec, J. A. \& Wöber, K. W. (eds) (2009). Analysing international city tourism. Vienna-New York: Springer, 524.

Wolk, A. \& K. Wöber (2008). Dimensions of tourist information needs across different European destinations according to search terms entered on a tourism-specific search engine. Journal of Information Technology and Tourism, 10(2), 119-131.

Xiang, Z. \& Fesenmaier, D. (2005). An analysis of two search engine interface metaphors for trip planning. Information Technology and Tourism, 7(2), 103117.

Xiang, Z. \& Fesenmaier, D. (2006). Assessing the initial step in the persuasion process: Meta tags on destination marketing websites. Information Technology and Tourism, 8(2), 91-104.

Xiang, Z., Gretzel, U. \& Fesenmaier, D. (2009). Semantic representation of tourism on the Internet. Journal of Travel Research, 47(4), 440-453.

Xiang, Z., Wöber, K. \& Fesenmaier, D. (2008). Representation of the online tourism domain in search engines. Journal of Travel Research, 47(2), 137-150. 